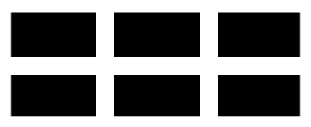

THE WILLIAM DAVIDSON INSTITUTE AT THE UNIVERSITY OF MICHIGAN BUSINESS SCHOOL

\title{
Organized Labor and Restructuring: Coal Mines in the Czech Republic and Romania
}

By: Jan Bruha, Delia Ionascu, and Byeongju Jeong

William Davidson Institute Working Paper Number 773

May 2005 


\title{
ORGANIZED LABOR AND RESTRUCTURING: COAL MINES IN THE CZECH REPUBLIC AND ROMANIA
}

\author{
Jan Bruha, Delia Ionascu, and Byeongju Jeong* \\ CERGE-EI \\ P.O.Box 882, Politickych veznu 7 \\ 11121 Prague 1 \\ Czech Republic \\ byeongju.jeong@cerge-ei.cz
}

March 2005

\begin{abstract}
We examine the role of organized labor in the restructuring experience of two coal mining regions in the 1990's: Ostrava in the Czech Republic and the Jiu Valley region in Romania. Under similar external circumstances, the Ostrava region undertook gradual restructuring from early on whereas in Jiu Valley there was no restructuring until 1997, followed by massive layoffs over two years. We conduct a quantitative exercise that accounts for the mine productivity, the labor market conditions, and the constraints in compensating the laid-off miners. We show that the delay in restructuring in Jiu Valley was inefficient: gradual restructuring with compensation would have benefited both the miners and the government. The proximate reason for the delay was the Jiu Valley miners' action against restructuring. We interpret their action in part as a behavioral pattern under a perceived threat to their livelihood. This accords with their history of militancy in contrast to Ostravian miners.
\end{abstract}

Keywords: organized labor; restructuring; coal; transition; welfare JEL classification: O17; J50; P31; R11

\footnotetext{
* We are grateful for funding from the Global Development Network. We thank seminar participants at CERGE-EI, the Global Development Network Workshop in Prague, the International Society for New Institutional Economics Conference in Boston, the European Association of Labor Economists Conference in Seville, and the Universitat Pompeu Fabra in Barcelona for helpful comments.
} 


\section{Introduction}

Organized labor is often characterized as an obstacle to economic progress. General versions of this view can be found in Olson (1982) and Parente and Prescott (2000), who designate the rent-seeking and rent-preserving activities of interest groups such as labor unions and professional associations the key factor in stagnating economies. ${ }^{1}$ This aspect of organized labor is likely to be most visible when the status quo is challenged. In this paper we conduct a case study of such an episode in the restructuring of coal mines in the Ostrava region in the Czech Republic and the Jiu Valley region in Romania. The initial motivation for this research came from reading about a violent protest by the Jiu Valley coal miners,${ }^{2}$ which turned out to be a pattern in the restructuring experience of the region. Our objective is to clarify the nature of such an action with a view toward evaluating the connection between organized labor and economic progress. ${ }^{3}$ Did the miners' action indeed hinder the path of efficient restructuring? If so, what are the underlying reasons for, and the corroborating factors of, such an action? Along the way, we make useful comparisons with Ostrava's restructuring experience, which was markedly peaceful despite similar external conditions.

In Section 2, we describe the restructuring experiences of the two regions, Ostrava and Jiu Valley. At the beginning of the 1990's, both regions went through a sharp decline in coal production as national industrial drive ceased. Gradual restructuring, mostly downsizing of employment, followed in the Ostrava region. In the Jiu Valley region, on the other hand, there was no restructuring at all until 1997, when the new progressive government managed to carry out massive layoffs over two years. The layoffs created a crisis in the regional labor market. As alluded to above, there was a sharp contrast in the miners'

\footnotetext{
${ }^{1}$ For the opposite view that various associations can facilitate politico-economic modernization, see Putnam (1992).

${ }^{2}$ See The Economist (1999).

3 The spirit of this research is shared by Galdon-Sanchez and Schmitz (2002), who study the change in labor productivity under increased competition in the worldwide iron-ore industry.
} 
behavior toward restructuring between the regions. The Ostravian miners cooperated with the government throughout, whereas the Jiu Valley miners fought not only against restructuring the region's mines but against the reformist agenda in general. The extreme swing in the Jiu Valley restructuring path reflected the initial success and subsequent failure of the miners' action in the context of national politics.

In Section 3, we conduct a quantitative exercise in order to evaluate how (in)efficient the restructuring paths were in the two regions. The presumption would be that the extreme swing in the Jiu Valley restructuring was socially inefficient: either the early stagnant phase or the later massive-layoff phase would have been inefficient. In comparison, the steady pace of Ostrava's restructuring would seem efficient. By explicitly modeling the optimal path of restructuring, we obtain a degree of clarity on the aspects of the actual restructuring path that were inefficient, which would then need to be explained. Our method is to estimate the value of the (laid-off) miners' labor both inside and outside the mines, taking into consideration the expected unemployment duration, which depends on the restructuring path. We take the discounted sum of this value to be the measure of efficiency. We show that in both regions the most efficient path would have been a largescale layoff over the first few years. The actual restructuring path of Ostrava was not far from the most efficient one whereas that of Jiu Valley was far from it: the efficiency-loss (i.e., the efficiency-gap between the most efficient and the actual path) was three times greater in Jiu Valley than in Ostrava. Therefore, our exercise mainly supports the view that the delay in restructuring Jiu Valley mines was socially inefficient.

In Section 4, we address why restructuring was delayed in Jiu Valley. The proximate reason is the aforementioned miners' action against restructuring. We extend our quantitative exercise and show that gradual restructuring with severance payment under a reasonble government budget constraint would have benefited both the miners and the government. The miners' action is hard to rationalize in light of our exercise and the individual miners' receptive response to the restructuring initiative by the later government. 
We interpret the miners' action in part as a behavioral pattern under a perceived threat to their livelihood. The historical militancy of Jiu Valley miners, in contrast to Ostravian miners, accords with this interpretation. We also discuss the corroborating factors for the miners' action, in particular the miners' alliance with the conservative faction of the government. A probable motivation for the conservative faction was the sheer violence that could be unleashed by the miners toward political opponents. In the end, the success and failure of the miners' actions were determined by the Romanian population. When the electorate turned against the alliance, it crumbled and the miners were finally defeated as a political force.

In Section 5, we summarize the results and draw an overall conclusion.

\section{Restructuring Experiences of the Two Regions}

In this section, we describe the restructuring experiences of Ostrava and Jiu Valley based on, among other sources, the interviews that we conducted. ${ }^{4}$ Each of the two regions is a well-defined geographic and economic zone ${ }^{5}$ that produces virtually all deep-mined black coal in the respective country. In the 1980's, coal production was highly valued as a source of energy: the national production structure was skewed toward energy-intense heavy industries. With the beginning of transition came an abrupt decline in industrial production, which led to a sharp reduction in coal production. In Ostrava the reduction was on the order of 10 to 25 percent stretching over a couple of years; in Jiu Valley it was nearly 50 percent, all within the first year. Thus a sort of 'demand' shock set the stage for restructuring. Gradual restructuring, mostly downsizing of employment, followed in the

\footnotetext{
4 We interviewed government officials, mining company managers, union representatives, and researchers. Five interviews were in Prague and Ostrava in 2002, and fourteen in Bucharest, Jiu Valley, and Cluj in 2002 and 2003. These were complemented by previous studies, mainly sociological studies on the effects of restructuring in Jiu Valley, which are referenced throughout.

5 To be precise, the Ostrava region refers to the districts of Ostrava and Karvina in northern Moravia, and the Jiu Valley region refers to the townships of Petrosani, Aninosa, Lupeni, Petrila, Uricani, and Vulcan in Hunedoara County.
} 
Ostrava region. In contrast, in the Jiu Valley region there was no restructuring at all until 1997, followed by massive layoffs over two years. Tables 1 and 2 present the production and employment figures from 1990 to $2001 .^{6,7}$ Figures 1 and 2 visualize the strikingly different paths of restructuring between the two regions.

The differences in the two regions' paths of restructuring mirrored those of the national economies. The Czech Republic made gradual, steady progress toward a market economy. Starting further away from a market economy, Romania undertook few reforms until a new government came to power in 1996. Between the two regions there was a marked difference in the miners' behavior toward restructuring. In the Ostrava region, the miners' union cooperated with the government - and the government consulted with the union - which led to a peaceful process of restructuring despite the significant decline in employment. In the Jiu Valley region, in contrast, the miners' union was not only against mining restructuring but was an active conservative force in national politics. Notably, miners made marches to Bucharest, called mineriadas, on several occasions to violently quell the progressive movement. In 1997, however, the new government managed to carry out massive layoffs using a carrot and stick approach: it provided severance payments of up to 20 months of wages while keeping the charismatic union leader Miran Cozma in jail. When the released Cozma mounted another mineriada in 1999, the government outwitted him and put him back in jail with a 17 year sentence; the miners were finally defeated as a political force.

6 The data for Ostrava are from the yearbooks published by the Czech Mining Institute; the data for Jiu Valley were directly obtained from the CNH, the only mining company in the region. We cautiously present the 1990 data for the Ostravian mines: their only source is the 1993 yearbook and the data from this yearbook are in general somewhat different from the subsequent yearbooks. For both regions the employment figures are for the workers in mines, excluding the headquarters and auxiliary units. Much of the change in the number of these excluded workers represents spin off units (e.g., social service) that are not directly related to mining. We focus on the restructuring of mines proper and abstract from this peripheral issue.

7 The improvement in labor productivity is largely due to downsizing. In particular, the Jiu Valley mines had a large slack in labor until 1997, given the large initial decline in output. Further, there was little investment in new technology in Jiu Valley throughout the period. Some Ostravian mines, however, adopted new technology in the early years, which contributed to the improvement in productivity. 
The gradual and steady pace of the Ostravian restructuring path resulted in a favorable unemployment experience for the ex-miners, whereas the delayed and massive layoffs in Jiu Valley created a crisis in the labor market. This can be seen in the unemployment rates presented in Tables 1 and $2 .^{8}$ The contrasting unemployment situation stemmed in part from the initial condition. Jiu Valley is an isolated mono-industrial region and could offer few opportunities to ex-miners. The Ostrava region had a larger and more diversified labor market, and could absorb layoffs with relative ease until the late 1990's, when the restructuring of the metallurgical industry strained the market. ${ }^{9}$ There was also a marked difference in the ex-miners' behavior toward job searches. The Ostravian ex-miners took more initiatives to find work and had a reputation for making good workers in new occupations. The Jiu Valley ex-miners, on the other hand, were more reluctant to accept low-wage work and had a tendency to protest for governmental help. Notably, following the massive layoffs some ex-miners mounted a hunger strike in order to obtain benefits from the government, which became routinized. ${ }^{10}$

\footnotetext{
8 The labor market data were directly obtained in various bits from the statistics and labor offices at both the regional and national levels. We constructed unemployment rates by subtracting the official employment figure from the labor force. The official unemployment rates only measure registered unemployment, which underestimates unemployment during the downturn of the labor market. This problem was in particular clear and significant in Jiu Valley in the late 1990's. Incidentally, the official labor force is measured by summing up the official employment and unemployment figures. For the Ostrava region we fixed the size of the labor force at the average over the period since there was little population growth or immigration during the period. For the Jiu Valley region the labor force was held at the average until 1996, and afterwards adjusted year-by-year by subtracting the significant net-immigration out of the region. Finally, note the implausibly low unemployment rate in Ostrava in 1996, which is due to an obvious error in the raw data for this year. Not knowing the magnitude of the error, we left it uncorrected.

9 A 1996 European Union assessment of the labor market conditions of 21 European coal mining regions ranked the Jiu Valley region as the fourth most 'vulnerable' to restructuring, and the Ostrava region as the third least vulnerable (see European Union 1996).

10 The hunger strike should be understood euphemistically: most participants left the protest site in the evening, presumably discontinuing hunger. Further, the participants considered the granting of governmental benefits to non-participants as encouraging 'free riding,' which makes it clear that the participants perceived the strike as a legitimate means of obtaining personal benefits.
} 


\section{Evaluating the Restructuring Paths}

In this section, we quantitatively evaluate the efficiency of the restructuring paths in the two regions, taking into consideration the productivity inside the mines relative to outside, and the unemployment duration following layoffs. Our main objective is to assess whether the delay of restructuring in Jiu Valley was inefficient in the context of the overall restructuring path. At the outset, it is possible that the delay was relatively benign when compared to the massive layoff that followed, or even to the milder but significant layoffs in Ostrava early on.

\subsection{Measuring the Value of Labor inside Mines}

To measure the value of miners' labor in coal production, we start with the following production function:

$$
Y_{t}=A_{t} K_{t}^{\alpha} L_{t}^{\gamma}
$$

where $Y_{t}$ is the output, $A_{t}$ is the technology parameter, $K_{t}$ is all non-labor input, including not only capital but also material input, and $L_{t}$ is labor input. To assess non-labor input during restructuring, we consulted the accounts of the dominant mining companies, the OKD in Ostrava and the CNH in Jiu Valley, for the 1993-2000 period. ${ }^{11}$ The non-labor input cost as a share of revenue is on average .59 and .48, respectively, and there is no upward or downward trend in either company. Based on this, we assume that the observed shares are maintained throughout restructuring, ${ }^{12}$ so (1) becomes

$$
Y_{t}=\mu^{\frac{\alpha}{1-\alpha}} A_{t}^{\frac{1}{1-\alpha}} L_{t}^{\frac{\gamma}{1-\alpha}}
$$

11 The OKD produces about $80 \%$ of Ostrava's coal and, as mentioned, the CNH is the only mining company in Jiu Valley. The accounts for the earlier years were not publicly available.

12 To elaborate on the rationale for constancy, it is plausible that the OKD could choose output and non-labor input (but not labor input) throughout the period. Then the marginal product of non-labor input would have been equal to the input price level, which implies that the non-labor input share was equal to $\alpha$ in (1). The CNH, on the other hand, probably could not choose output (and labor input) freely due to its more rigid output market, leaving no prediction on whether the non-labor input share should increase or decrease as we move from the early to the late 1990's: the 1997-1998 layoff would have increased the share of non-labor input as a substitute, but the accompanying reduction of output would have had the opposite effect. The $\mathrm{CNH}$ account suggests that the two effects roughly canceled each other out. 
where $\mu$ denotes the non-labor input share.

The technology parameter $A_{t}$ reflects factors such as the upgrading of equipment, the change in work practice, and the temporary impact of closing mines, which are important but not dominant aspects of restructuring in our case (see footnote 7 ). Since our focus is on labor downsizing, we simply assume that these other aspects of restructuring keep pace with labor downsizing, i.e., $A_{t}$ depends only on $L_{t}$. Further, we assume that the impact of $A_{t}$ on the production function is to make it linear with respect to $L_{t}$ during restructuring, so (2) becomes

$$
Y_{t}=\bar{Y}+\tilde{A}\left(L_{t}-\bar{L}\right)
$$

where $\bar{Y}$ and $\bar{L}$ are the final fixed levels of output and employment. The production function (3) is drawn as solid lines in Figures 1 and $2 .{ }^{13}$ The function approximates the actual path of restructuring for the Ostrava region, while there is little reason to consider a more complex function for the Jiu Valley region. To emphasize, (3) is assumed to be valid during the 1990-2001 restructuring period and is not meant to be a long-run production function.

The value of $\tilde{A}$, when production is measured at an annual rate, is 150 tons/worker for the Ostrava region and 52 tons/worker for the Jiu Valley region. The coal price, when measured in USD, was stable over the period except in the early 1990's in Ostrava and in the late 1990's in Jiu Valley, and there is no trend upward or downward over the whole period in either region. ${ }^{14}$ Avoiding the nominal noises of the unstable periods, we fix the price at the average, which was 35.4 USD and 22.5 USD, respectively. The upshot of all this

13 For the Ostrava region, the function is drawn through the 1991 point rather than the 1990 point. The large output drop from 1990 to 1991 largely represents the initial demand shock, as mentioned in Section 2, rather than restructuring.

14 The price was measured by dividing revenue by production volume and then converting this value to USD according to the current exchange rate. If we discount the price by the Consumer Price Index instead, we obtain the same periods of instability and a somewhat downward trend over the whole period, which is expected since the real value of USD depreciated over time. 
is that the value of output that accrued to the would-be-laid-off miners is $p(1-\mu)\left(Y_{t}-\bar{Y}\right)$ in units of the current-period USD, where $p$ denotes the coal price.

\subsection{Measuring the Value of Labor outside Mines}

To measure the value of ex-miners' labor, we start with the following job-finding function:

$$
M_{t}=B U_{t}^{\rho}
$$

where $M_{t}$ is new employment, $U_{t}$ is unemployment, $B$ is a parameter that indicates the labor market condition aside from unemployment, and $\rho$ is an elasticity parameter. Let $\phi_{t}$ denote the job finding rate: $\phi_{t} \equiv M_{t} / U_{t}$. The reciprocal of this rate is the expected unemployment duration (i.e., the duration that would be obtained if the rate is maintained into the future). We can estimate the job-finding rate, or equivalently the expected unemployment duration, from the panel data of actual unemployment duration: in each period we follow the cohort of the newly unemployed and see how many of them remain unemployed in the following period. Estimated this way, in the Ostrava region the expected unemployment duration increased from 7.8 months in the 1993-1995 period to 18.2 months in the 1999-2001 period, an increase by a factor of $2.3{ }^{15}$ Between the two periods, unemployment increased by a factor of 3.0, which implies that $\rho=.24$ for the Ostrava region. In the Jiu Valley region, unemployment increased by a factor of 4.0 from the 1993-1996 period to the 1999-2000 period. We could estimate that the expected unemployment duration in the latter period was about three years. ${ }^{16}$ For the former period, we can only guess that the expected unemployment duration may have been about one year, based on peripheral

\footnotetext{
15 We could only obtain the annual data of unemployment duration for the greater Ostrava region, which is composed of five districts including the two districts of our interest, Ostrava and Karvina. Since the drop in the job-finding rate may have been more severe in the two-district region, the following estimate of $\rho$ may be an overestimate.

16 This is based on Chiribuca, et al. (2000) and the annual data of unemployment duration for Hunedoara county that includes Jiu Valley.
} 
information. ${ }^{17}$ Assuming the three-fold increase in the expected unemployment duration between the periods, we have $\rho=.21$ for the Jiu Valley region. ${ }^{18}$ Given the values of $\rho$, we can calculate from (4) that when new employment is measured on a monthly basis, the parameter $B$ is equal to 222 for the Ostrava region and 97 for the Jiu Valley region.

Now we specify the unemployment inflow that feeds into the job-finding function (4). Let $\hat{U}_{t}$ denote the unemployment of ex-miners, and $\check{U}_{t}$ that of the others: $U_{t}=\hat{U}_{t}+\check{U}_{t}$. The unemployment inflow of miners is given by the layoff path: $\hat{U}_{0}=0$ and

$$
\hat{U}_{t+1}=\left(1-\phi_{t}\right) \hat{U}_{t}+L_{t}-L_{t+1} .
$$

Similarly, we have

$$
\check{U}_{t+1}=\left(1-\phi_{t}\right) \check{U}_{t}+Z_{t+1},
$$

where $Z_{t}$ is the inflow of non-ex-miners. We set $\check{U}_{0}$ and $Z_{t}$ so that the sequence of total unemployment corresponds to the data under the actual layoff path. Recall that in both regions unemployment was steady until 1997, after which it became significantly worse. In Ostrava the worsened situation was largely due to the layoffs in the metallurgical industry, unrelated to mining restructuring. Accordingly, we set

$$
Z_{t+1}=\phi_{t} \check{U}_{0}
$$

for all periods except for the 1997-2000 period, and

$$
Z_{t+1}=\phi_{t} \check{U}_{0}+\bar{Z}
$$

17 Based on the annual data of unemployment duration at the national level, we estimated the expected unemployment duration to be about one year in the mid-1990's. The unemployment rate of Jiu Valley was comparable to the national average prior to 1997. Our guess would be valid if the labor market conditions aside from the unemployment rate (i.e., scale-adjusted $B$ in equations 4 and 5) were comparable, too.

18 The lack of precision for $\rho$ is not crucial for the main result, as the sensitivity analysis in Section 3.3 shows. 
for the 1997-2000 period, where $\bar{Z}$ is a fixed additional layoff. In Jiu Valley the worsened situation was virtually entirely due to the layoffs in mining and those linked to mining. To preserve this linkage under various layoff paths, we set

$$
Z_{t+1}=\phi_{t} \check{U}_{0}+\theta\left(L_{t}-L_{t+1}\right)
$$

for all periods, where $\theta$ is the additional layoff as a fixed fraction of the mining layoff. ${ }^{19}$ The values of $\check{U}_{0}$ and $\bar{Z}$ that best simulate the monthly unemployment path for Ostrava were 14,900 and 2,500; the values of $\check{U}_{0}$ and $\theta$ that do the same for Jiu Valley were 8,000 and $.78 .^{20}$

Now we can calculate the sequence of ex-miners' employment using (4) to (9):

$$
N_{t+1}=N_{t}+\phi_{t} \hat{U}_{t}
$$

where $N_{t}$ denotes the ex-miners' employment. ${ }^{21}$ We estimate the value of newly employed ex-miners' labor using the actual wages in the regions. In the Ostrava region, the gross annual average wage ${ }^{22}$ when measured in units of coal and then converted to USD, ${ }^{23}$ was 3,507 USD in 1990 and grew at an annual rate of $4.5 \%$ on average over the years, reaching 5,709 USD in 2001. In the Jiu Valley region, for the 1993-2000 period the same method

19 There would have been extra unemployment linked to mining in Ostrava as well, although we don't know its size. Since the extra unemployment linked to mining would lead to a slower pace of optimal restructuring, the bias resulting from the modeled asymmetry between the regions is a safe one: it reinforces the result that the actual restructuring path in Ostrava, although slower than the optimal one, was closer to optimal than in Jiu Valley.

20 Recall that there was a significant emigration out of Jiu Valley in the late 1990's, no doubt as a consequence of the massive layoffs (footnote 8). Since $\theta$ is calibrated to the unemployment path in Jiu Valley, its value is net of the emigration of those laid-off, including ex-miners.

21 Here we have assumed that the job-finding rate of the emigrant ex-miners is the same as that of the miners who stayed (see the previous footnote). We are not sure about the employment prospects of the emigrant ex-miners, but they were probably not very different from those of the ex-miners who stayed. Many of the emigrants returned after a while, unable to find work elsewhere.

22 That is, before any taxes including the social security tax paid by the employer. The gross wage is the proper measure of the market value of labor.

23 Thus we are measuring the value of labor both inside and outside mines in units of coal, and then multiplying it by the price of coal, which is assumed to be fixed in USD (see Section 3.1). Again, the fixed-price assumption avoids the nominal noises of periods when prices were unstable. 
yields an average wage of 2,530 USD and a virtually zero growth rate. Let $w_{t}$ denote the growth path of the gross average wage as described here. For the years beyond 2001, we assume that in both regions the annual growth rate of $w_{t}$ will adjust gradually to a more typical rate of $2.0 \%$ during the 2001-2005 period, and thereafter stay at this rate. How did the ex-miner's wage compare to the average wage in the regions? In Ostrava it was probably not far off from the average wage since ex-miners seem to have had little difficulty in adjusting to new occupations. In Jiu Valley, in contrast, ex-miners had great difficulty in adjusting to new occupations, and their wage was as low as half of the average wage in the region. ${ }^{24}$ Let $\lambda$ denote the ex-miner's wage as a share of the gross average wage. As a benchmark, we assume that $\lambda$ is equal to 1.00 in Ostrava, and to .75 in Jiu Valley. Putting all this together, the value of the ex-miners' labor is $\lambda w_{t} N_{t}$ in each period.

\subsection{Measuring the Efficiency of Restructuring Paths}

Now we are ready to evaluate the paths of restructuring, using the above calibrated model. Let $W_{t}$ denote momentary welfare, that is, the value of (laid-off) miners' labor both inside and outside the mines: $W_{t} \equiv p(1-\mu)\left(Y_{t}-\bar{Y}\right)+\lambda w_{t} N_{t}$. Let $\left\{L_{t}^{a}\right\}$ denote the actual layoff path and $\left\{W_{t}^{a}\right\}$ the actual welfare path associated with $\left\{L_{t}^{a}\right\}$. This welfare path, as an annual rate, is depicted by the solid lines in Figures 3 and 4, with the 1990 level normalized as zero. In the Ostrava region, $W_{t}^{a}$ has been increasing gradually in accordance with the gradual restructuring, except for a mild dip in the late 1990's due to the worsened unemployment situation. In the Jiu Valley region, $W_{t}^{a}$ changed little until 1997, after which a large downward and then upward swing followed due to the massive layoff.

24 This figure is the estimate from Chiribuca, et al. (2000). However, some of this differential is probably transitory and reflects the temporarily worse labor market conditions and the trial-and-error aspect of a job search. Ex-miners typically worked as laborers in construction, in public-works repair, and in the black market (Larionescu, Rughinis, and Radulescu 1999). 
The welfare proper is the discounted sum of momentary welfare, and the optimal layoff path, denoted by $\left\{L_{t}^{o}\right\}$, is the one that maximizes welfare:

$$
\left\{L_{t}^{o}\right\}=\arg \max \left\{\sum_{t=1}^{\infty} \beta^{t} W_{t}: L_{t} \geq \bar{L} \text { and (3) to (10) }\right\},
$$

where $\beta$ is the discount rate. ${ }^{25}$ Since the labor market flows are on a monthly basis, we set the period to be month-long and adjust output and wage accordingly. We assume that $\beta=.995$, which is equivalent to an annual discount rate of about $6 \% .{ }^{26}$ We solved this maximization problem numerically. Given a sequence of $L_{t}$, we can calculate the expected discounted sum of the value of a miner's labor, which only depends on the timing of his layoff. Further, we can calculate the externality that a miner imposes on the other miners by congesting the labor market, ${ }^{27}$ which again only depends on the timing of his layoff. The timing of layoffs can then be ordered by the expected discounted sum of the value of a miner's labor net of his externality. By construction, we can increase welfare by moving the timing of layoffs from a low-value period to a high-value period. Starting with an arbitrarily chosen sequence of $L_{t}$, we updated it repeatedly by moving the timing of a single miner's layoff from the lowest-value period to the highest-value period until all layoff periods had the highest value.

Let $\left\{W_{t}^{o}\right\}$ denote the optimal welfare path associated with the optimal layoff path $\left\{L_{t}^{o}\right\}$. This welfare path is depicted by the dashed lines in Figures 3 and 4 . For both regions, there is a sharp initial decline which indicates a massive layoff. In Ostrava, $63 \%$ of all layoffs take place in the first month, and the entire period of layoffs lasts 16 months. Even more dramatic, in Jiu Valley the period of layoffs lasts only 4 months, with $97 \%$ of

25 Note that the sum is over the infinite horizon. This is conceptually proper if we view restructuring as a reallocation of labor that by default will be maintained indefinitely.

26 Since the price and the wage are in units of current USD, the discount rate is a combination of the depreciation of the currency and time preference.

27 See equation 4 . Note that we are abstracting from the externality that miners impose on non-miners or vacant firms in the labor market. Whether this externality is overall positive or negative would depend on the labor market properties, in addition to those that we have assumed. 
all layoffs occurring in the first month alone. At the beginning of the 1990's, under the benchmark parameter values, the value of a miner's labor in mining as a share of that in alternative employment is $62 \%$ in Ostrava and $32 \%$ in Jiu Valley. These value differentials largely outweigh the congestion effect of a massive layoff on the labor markets, which were initially in fair condition. Subsequent to the massive layoffs, $W_{t}^{o}$ rises as ex-miners find jobs. The unemployment duration, on average across ex-miners, is 12 months in Ostrava and 30 months in Jiu Valley. The shorter duration for Ostrava is because of a larger local labor market: the unemployment rate is maintained below 15\% throughout, while in Jiu Valley it reaches over $50 \%$ in the first few months. ${ }^{28}$ The transitional impact of restructuring is over within the first two or three years in Ostrava and by the middle of the 1990's in Jiu Valley, after which $W_{t}^{o}$ follows the respective wage growth in the regions. The overall inefficiency of actual restructuring can be measured as the difference in welfare (i.e., the sum in (11)) between the optimal and the actual paths as a share of welfare under the optimal path, i.e., $\sum_{t=1}^{\infty} \beta^{t}\left(W_{t}^{o}-W_{t}^{a}\right) / \sum_{t=1}^{\infty} \beta^{t} W_{t}^{o}$. This measure of inefficiency is $8.8 \%$ for the Ostrava region, and $26.7 \%$ for the Jiu Valley region. Thus the actual restructuring path was three times more inefficient in Jiu Valley than in Ostrava.

The main result of the exercise is that the delay of restructuring in Jiu Valley was indeed inefficient. The layoff of 1997, on the other hand, is justifiable: given that there was no restructuring until then, the optimal path would be a massive layoff as occurred. In Ostrava the pace of restructuring should have been faster too, but the welfare loss is much smaller than in Jiu Valley since there was a substantial layoff from early on while the case for a massive layoff is weaker than in Jiu Valley. A natural question is how sensitive the results are to the assumed parameter values. In this regard there are three

28 The relatively favorable labor market outcome in Ostrava may be an exaggeration since we have assumed extra unemployment linked to, and in proportion to, mining unemployment in all periods in Jiu Valley, but not in Ostrava (see Section 3.2). If we assume extra unemployment linked to mining in Ostrava as well, the resulting unemployment rate would be higher although this effect would be mitigated by the slower restructuring pace (see Footnote 19). Regardless, under any reasonable size of extra unemployment, a large difference in the labor market outcome between the regions would remain. 
key parameters, the productivity parameter $\tilde{A}$, the ex-miner's wage factor $\lambda$, and the jobfinding elasticity $\rho$. The first two parameters matter only as a ratio, i.e., holding $\tilde{A} / \lambda$ constant, any change leads to only a re-scaling of welfare (see (11)). To see the extent to which the pace of optimal restructuring can be slowed down, we increase this ratio by $50 \%$, which is probably the reasonable upper bound. We also set $\rho=0$, which implies that job creation is completely irresponsive to an increase in unemployment. Under these sets of values, the initial layoff as a percentage of the entire layoff decreases to $21 \%$ in Ostrava and to $44 \%$ in Jiu Valley, and the layoff duration increases to 50 and 68 months, respectively. Therefore, the optimal restructuring path is moderate relative to the benchmark, but still exhibits quicker layoffs than the actual path. ${ }^{29}$

\section{Explaining The Restructuring Paths}

In this section, we address the central question that emerges from the quantitative exercise: why was restructuring delayed in Jiu Valley? At the center of our explanation is the miners' action against restructuring. The miners were a force to be reckoned with not only in mining restructuring but also in national politics. The mineriadas, the miners' marches, in the early 1990's were effective in suppressing progressive voices such as intellectuals and students as well as right-wing politicians. Without the miners' action, the structural reform of the economy would have proceeded faster and, in particular, some kind of mining restructuring would probably have occurred in the early 1990's.

\subsection{Gradual Restructuring with Transfer Payments}

We first examine whether the difficulty of extracting the benefits from early restructuring led the miners to pursue a delay in restructuring. Our strategy is to see whether we could design a plausible transfer scheme that would have benefited both the miners

29 The inefficiency measure for the actual path, under these alternative parameter values, is $5.6 \%$ in Ostrava and $26.5 \%$ in Jiu Valley. The small change in inefficiency from the benchmark in Jiu Valley is the result of two off-setting effects: the inefficiency of inaction in the early 1990's is reduced but the speed of layoffs in the late 1990's becomes too fast. 
and the government. An implicit assumption is that the welfare effects of actual restructuring on the miners and the government represent what both parties could expect at the beginning of the 1990's. We will discuss the consequences of relaxing this assumption in Section 4.2. We focus on a lump-sum severance payment, which was the means of compensation in actual restructuring. We doubt that a more sophisticated transfer scheme could have worked. For example, severance payment in installments would have allowed a greater flexibility in restructuring paths but it would not have appeared credible: there was a general lack of trust in the government and, once laid off, the miners might not have been able to make the government stick to its side of the bargain. ${ }^{30}$ Given that optimal restructuring requires a massive layoff at the beginning of 1990's, the main difficulty of the scheme is its financing: the government was not running budget deficits but its ability to borrow was limited, which reflects its lack of credibility among creditors. ${ }^{31}$ This limits the pace of restructuring to be gradual.

Let $G_{t}$ denote the net government spending on miners in period $t$ given layoff path $\left\{L_{t}\right\}$ and severance payments $\left\{s_{t}\right\}: G_{t} \equiv \tilde{\lambda} w_{t}(1-\tau) \cdot L_{t}-p(1-\mu) Y_{t}+s_{t}\left(L_{t-1}-L_{t}\right)-\lambda \tau w_{t} N_{t}$, where $\tilde{\lambda}$ denotes the miner's wage premium and $\tau$ the tax on wages. The first two terms are the net spending on current miners, the second term the severance payments, and the third term the tax revenue from ex-miners. The miner's wage was about $63 \%$ above the average wage in Jiu Valley in the $1990 \mathrm{~s}$, so we set $\tilde{\lambda}=1.63$. We set $\tau=.46$, which includes the social security and income taxes. ${ }^{32}$ The actual severance payments ranged from 12 to 20 months of the miner's wage during the large layoff starting in 1997 . For the actual restructuring path, we approximate the severance payments by setting $s_{t}$ to be 16

\footnotetext{
30 More generally, there is an argument that the workers' unions fight over the size of membership as a means of ensuring future rents. See Acemoglu and Robinson (2001) for a formal treatment of this.

31 The government was widely perceived as unreformed ex-communists. The miners' action itself significantly contributed to this perception (see Section 4.3). Had the miners and the government pursued early restructuring as envisioned here, the creditors may have been more receptive.

32 The employer paid about $38 \%$ of wages as social security tax. The employee paid about $25 \%$ of wages as income tax. So, the total tax rate is $(1-25 \%) /(1+38 \%)$.
} 
months of a miner's net wage from 1997 to 1999, and to be zero otherwise. For the gradual restructuring path, we fix $s_{t}$ at a level denoted by $\bar{s}$. We assume that the budget constraint allows a fixed per-period expense $B$ in addition to the actual expenses on miners: for all $T \geq 1$,

$$
\sum_{t=1}^{T} \beta^{t}\left(G_{t}^{g}-G_{t}^{a}-B\right) \leq 0,
$$

where $G_{t}^{a}$ denotes the spending under actual restructuring and $G_{t}^{g}$ that under gradual restructuring.

Given $B$ and $\bar{s}$, the gradual layoff path is given by the right-hand side of (11) with (12) as an additional constraint. A higher value of $B$ allows for faster restructuring. We base its value on the actual government spending on the mines at the beginning of the 1990's. The total wage bill (i.e., $\tilde{\lambda} w_{0} L_{0}$ ) was 138 million USD in annual rate. It becomes 79.9 million after subtracting the sales revenue (i.e., $p(1-\mu) Y_{0}$ ), and 16.7 million USD after further subtracting the tax revenue (i.e., $\tau \tilde{\lambda} w_{0} L_{0}$ ). We consider $50 \%$ of the final figure within the reasonable range of additional spending, and set $B$ equal to 8.4 million USD annually. This is modest in comparison to about 49 million USD that the government spent on severance payments in 1997 when it initiated the layoff. The values of $\bar{s}$ are limited by the condition that the scheme should benefit both the miners and the government. Let $\rho$ denote the government share of the welfare gain:

$$
\sum_{t=1}^{\infty} \beta^{t}\left(G_{t}^{a}-G_{t}^{g}\right)=\rho \sum_{t=1}^{\infty} \beta^{t}\left(W_{t}^{g}-W_{t}^{a}\right),
$$

where $W_{t}^{g}$ denotes the momentary welfare under gradual restructuring. A higher value of $\bar{s}$ implies a lower value of $\rho$, and vice-versa. Thus the gradual restructuring paths are parameterized by $\rho$ in between 0 and 1 .

Depending on $\rho$, the values of $\bar{s}$ range from 7,000 to 10,100 USD, or 37.5 to 54 months of a miner's net wage. The welfare gain (i.e., the right-hand side of (13) without $\rho$ ) ranges from 61.4 to 76.6 million USD, a higher value $\rho$ corresponding to a greater welfare gain 
due to a faster and therefore more efficient pace of restructuring. As a corollary, the first figure in the range is the upper bound in the miners' welfare gain, which translates to 3,300 USD, or 17.5 months of the miner's net wage, per laid-off miner. The layoff starts with 70 to 100 miners in the first month and gradually accelerates reaching 350 to 600 miners in the final months. ${ }^{33}$ The gradual acceleration is because the savings in the mines and the tax revenue from ex-miners accumulate allowing the government an increasing expense on severance payments. The entire duration of the layoff is 61 to 79 months, which implies that gradual restructuring would have been (nearly) over by the time when actual restructuring began. The dotted line in Figure 2 draws the welfare path under gradual restructuring when $\rho=.5$, in which case the miners and the government would have divided the welfare gain equally and we obtain approximately the mid-point in all the above ranges. In summary, gradual restructuring with a lump-sum severance payment scheme, under a reasonable government budget constraint, would have benefited both the miners and the government. ${ }^{34}$

\subsection{The Nature of the Miners' Action}

We now examine what motivated the miners' action against restructuring, aside from the difficulty of extracting the benefits from early restructuring and in the order of ease with which they can be reconciled with our quantitative exercise. One possibility is that the miners expected that restructuring could be delayed longer than it actually was, which would have increased their payoff from the delay. ${ }^{35}$ The issue is whether such an expectation was reasonable and whether it lowers the payoff from early restructuring relative

\footnotetext{
33 The 350 figure is after excluding the last seven months of layoff, when the layoff pace jumps above 700 a month, reflecting the jump in actual spending associated with the 1997 layoff.

34 We conducted a sensitivity analysis on $\tilde{A}, \lambda$, and $\rho$, as in Section 3 . The gradual restructuring path varies little across different values. This is because the budget constraint (12) is the binding constraint, little affected by these parameters.

35 A 1993-1994 survey conducted by the mining company CNH shows that a majority of employees believed that downsizing would occur, but they were much less concerned about its danger than that of inflation (see Krausz 1999).
} 
to that from the delay in restructuring. Perhaps, the miners expected that the demand for coal could recover after its initial collapse, which would have reduced the necessity of restructuring. There was no specific reason for such an expectation but there was a good deal of uncertainty about economic prospects in general. If we incorporate the possibility of recovery of demand into our exercise, it would slow down the optimal pace of restructuring but not to a halt, much like the transfer constraints do. In other words, uncertain demand makes a case for gradual restructuring rather than against it. Perhaps, the miners expected that the government would continue to pay for the loss in the mines instead of opting for the layoff in 1997. The 1997 layoff was indeed a consequence of the electoral success of reformist parties, which could not have been foreseen. If we incorporate the possibility of a further delay in restructuring into our exercise, however, the welfare gain from early restructuring becomes only larger and gradual restructuring with a greater level of transfer would benefit both the miners and the government in comparison to their expected payoffs from the delay.

Another possible motivation for the miners' action is that they were concerned about the unfair burden of restructuring on the laid-off miners. In our exercise, the welfare of a laid-off miner falls below that of a retained miner even under gradual restructuring with severance payment. For a miner who was 35 years old and had 20 years of remaining work life in 1990, his welfare loss would have been 3,200 to 6,400 USD, or 17 to 34.5 months of the miner's net wage, depending on the severance payment. This could be an underestimate since our exercise ignored the social costs of large unemployment such as the spread of alcoholism and higher crime and divorce rates, as observed in the aftermath of the 1997 layoff (see Larionescu, et al. 1999 and Kideckel 2000). Many of these costs would be borne by the laid-off miners themselves. Nonetheless, the advantage of early restructuring over delayed restructuring remains. A built-in feature of severance payment as a transfer method is to compensate precisely those who would suffer from layoffs, so the miners' welfare gain from early restructuring would go entirely to the laid-off miners. As 
mentioned, in our exercise the expected gain for a laid-off miner is up to 3,300 USD, or 17.5 months of the miner's net wage, equivalent to eliminating a half of the above-profiled miner's welfare loss. Consideration for social costs only strengthens the case for a gradual layoff since they are presumably the most acute when unemployment is concentrated in a short period.

The reasons discussed above are all based on the assumption that the miners' action was driven by their rational calculations in maximizing their welfare. Our view is that rational calculations fall short of fully explaining the miners' action. In particular, the rationale for the last mineriada of 1999 is hard to imagine: it took place facing the united progressive government after the massive layoff was nearly finished. The difficulty is compounded by individual miners' reactions to the restructuring initiative by the new government in 1997. The large number of miners who opted for the layoff was beyond expectation and the government had to take some measures to curb the layoff after the initial round. This is hard to reconcile with their collective behavior. In our exercise, the miners as a whole were excessively resistant to restructuring while they were individually excessively conducive to it. We do not have a rigorous explanation, but we believe that this is more than a mere characterization of the miners' behavior.

From our interviews and reading of the descriptive literature on the region, it emerged that group militancy may be a behavioral pattern of Jiu Valley miners under perceived threats to the status-quo. During the communist era, the miners acquired the reputation for militancy and considered themselves the backbone of labor. For example, the 1977 revolt, the last before the 1990's, was a reaction to the belt-tightening policy of industrialization under Ceausescu's regime, achieved various improvements in miners' livelihoods and heralded a series of similar actions in the other regions. At the same time, individual myopism may be another behavioral pattern of Jiu Valley miners. Chiribuca, et al. (2000) argues that it was irrational short-sighted behavior for the miners to accept the compensation package and become unemployed in 1997 and 1998 when they had little prospect of 
finding alternative employment. ${ }^{36}$ The authors point out that the less educated and thus lower-prospect miners were more likely to accept the compensation package. Most miners consumed away the compensation payment rather than use it to prepare themselves for new work (e.g., training, relocation). Having exhausted the payment, some miners resorted to ways of obtaining short-term benefits from the government rather than actively searching for new work, as highlighted by the hunger-strikes.

The behavioral pattern of Jiu Valley miners sharply contrasts with that of Ostravian miners. The latter did not have a history of revolt and confrontation, and in the 1990's cooperated with the government and carried out gradual restructuring from early on. Further, individual miners were proactive in looking for and adjusting to new work. Militancy as a behavioral pattern helps explain the events in the 1990's to the extent that they were predictable based on the (absence of) previous actions. Looking beyond the two regions of our inquiry, it is not new that a labor union may fight a losing battle to the end. A good example is the 1984 British coal miners' strike. ${ }^{37}$ The British miners went on a year-long strike against restructuring despite an offer of a generous severance payment. In the end the strike achieved nothing but lost pay and a ruined reputation for the miners. The miners, at least the union leadership, seem to have been driven by more than the narrow economic interests of the miners; perhaps they were driven by the ideology of socialist order or, more specifically, the involvement of the union in management decision making. The tripartite agreement, achieved ten years earlier through a series of strikes, indeed guaranteed something of this nature. The turning point was the attempt by the Thatcher government to nullify this arrangement. Under a threat to the status quo and under the memory of previous successful strikes, the miners may have been overly prepared for action, not unlike the Jiu Value miners.

\footnotetext{
36 The government may have chosen the compensation package rather than a more comprehensive labor conversion program because the compensation package minimized the resistance from the myopic miners. This is in line with the political aspect of restructuring, discussed in Section 4.3.

37 See Edwards and Heery (1989) for an excellent study of labor relations leading up to this episode.
} 


\subsection{The Corroborating Factors for the Miners' Action}

We now examine why the miners' action was effective in delaying restructuring. The miners received at least tacit support from the conservative faction within the government. Without it, their action could easily have failed as the later events under the successor government demonstrate. It is debatable how much of the support reflected the conservatives' stance on reform policy. Some, notably President Iliescu himself, may have genuinely believed that the reform could and should do without large-scale enterprise restructuring. They may have been hopeful of an economic turnaround without restructuring, being concerned about its social and distributive consequences. We examined these concerns as pertains to the Jiu Valley restructuring in Section 4.2. As mentioned, our view is that justifiable caution does not explain the absence of initiatives for Jiu Valley restructuring in the early 1990's. The Ostrava region did carry out substantial restructuring early on, even tough the initial demand shock and the necessity of restructuring were similar to, in fact within our exercise weaker than, those in Jiu Valley.

A more sinister reason for the conservatives' allying with the miners can be ascertained from the aforementioned miners' role in national politics. Notably, a 1991 mineriada forced the resignation of reform-minded Prime Minister Roman, the arch-rival of President Iliescu. It was widely believed that the conservative faction of the government called for the miners' action. Thus the conservative faction may have wanted to keep miners as a useful political force. Conversely, the massive layoff of 1997 under the progressive government may have been in part motivated by its desire to eliminate an opposition force while possible. ${ }^{38}$ This is a rationalization of the view, expressed by many in our interviews, that the new government took 'revenge' on miners for the earlier mineriadas. This aspect of the layoff corroborates with the fact that the final mineriada of 1999 seems to have taken place in alliance with the new nationalist party that tried to overthrow the government.

\footnotetext{
38 This interpretation can be couched in an extension of the argument in Footnote 30: a government tries to effect the size of a union as a means of ensuring the benefit, or eliminating the harm, from the union.
} 
The miners' action was ultimately arbitrated by the Romanian population. Although the mineriadas were an extra-legal method of influencing policy, they were sympathetically received by a large segment of the Romanian society. The electoral success of 1990 and 1992 gave basic strength to the conservative faction of the government, which was supplemented by the miners' action. Conversely, the election of 1996 drove out the conservative faction and installed the new progressive government, which was willing to confront the miners. When the alliance with the conservatives crumbled, the miners were outmaneuvered in the mineriada of 1999 and finally defeated as a political force. ${ }^{39}$ Therefore, the success of the miners' action was bound by its appeal to sections of the government and, by extension, to the population at large.

\section{Conclusion}

Our exercise shows that the delay in restructuring the Jiu Valley mines was indeed inefficient: it stands out as the main source of inefficiency in the overall restructuring path, all the more so when compared to Ostrava's restructuring path. Gradual restructuring with severance payment under a reasonable government budget constraint would have benefited both the miners and the government. Thus our exercise fails to (fully) explain the Jiu Valley miners' action against restructuring. Our view is that this failure lies in the strategy of explaining the miners' action based on their rational calculations in maximizing their welfare, rather than in the particular assumptions of the exercise. We interpret the miners' action in part as a behavioral pattern under a perceived threat to their livelihood. The historical militancy of Jiu Valley miners, in contrast to Ostravian miners, accords with this interpretation. Essential for the success of the miners' action was the alliance with the conservative faction of the government; the alliance itself was arbitrated by the Romanian electorate. We are admittedly vague about the development of militancy in Jiu Valley

39 The epilogue of this sequence of events is the reemergence of the conservative faction in the 2000 election. By then the main phase of mining restructuring was finished. 
and about the changes in the societal support for the miners' action. We can only muse that the Jiu Valley restructuring may represent a sort of adaptive learning experience for the Romanian society, whereby economic conflicts are increasingly resolved in the market rather than in the political arena. 


\section{REFERENCES}

Acemoglu, M. and Robinson, J. (2001), "Inefficient Redistribution," American Political Science Review 95:649-61.

Chiribuca, D., Comsa, M., Dincu, V., and Rotariu, T. (2000), "The Impact of Economic Restructuring in Mono-industrial Areas," SOCO Project Paper 87, Institute for Human Sciences, Vienna, Austria.

Czech Mining Institute (1993 - 2002), Mining Yearbook, Ostrava, Czech Republic.

Edwards, C. and Heery, E. (1989), Management Control and Union Power: A Study of Labour Relations in Coal-Mining, Clarendon Press, Oxford.

European Union (1996), Clean Coal Strategy for Central and Eastern Europe: Draft Status Review, Social Policy Analysis Group, Brussels.

Galdon-Sanchez, J. and Schmitz, J. (2002), "Competitive Pressure and Labor Productivity: World Iron-Ore Markets in the 1980's," American Economic Review 92:1222-35.

Kideckel, D. (2000), "A New 'Cult of Labor': Stress and Crisis among Romanian Workers," Sociologie Romaneasca 1:142-61.

Krausz, S. (1999), "Inertia of Mentality as a Break of Transition: An Example of Attitude toward the Downsizing of Economic Activities," in Sociology of Transition, Krausz, S., Ed., University of Petrosani, Petrosani, Romania. (In Romanian)

Larionescu, M., Rughinis, C., and Radulescu, S. (1999), With the Eyes of the Miner: The Reform of the Romanian Mining Sector, Gnosis, Bucharest. (In Romanian)

Olson, M. (1982), The Rise and Decline of Nations, Yale University Press.

Parente, S. and Prescott, E. (2000), Barriers to Riches, The MIT Press.

Putnam, R. (1992), Making Democracy Work: Civic Traditions in Modern Italy, Princeton University Press.

The Economist (1999), "Romania: All Very Sinister," Edition of February 6, London. 
Table 1: Ostrava Region

\begin{tabular}{|c|c|c|c|c|c|c|c|c|c|c|c|c|}
\hline Year & 1990 & 1991 & 1992 & 1993 & 1994 & 1995 & 1996 & 1997 & 1998 & 1999 & 2000 & 2001 \\
\hline \multicolumn{13}{|l|}{ Mines: } \\
\hline Production in thousand tons & 29,843 & 24,749 & 23,437 & 23,351 & 22,448 & 21,849 & 21,854 & 21,312 & 20,599 & 18,478 & 18,898 & 19,331 \\
\hline Employment in mines & 62,087 & 60,796 & 53,553 & 44,448 & 38,429 & 36,652 & 35,131 & 33,306 & 31,208 & 25,140 & 22,714 & 21,482 \\
\hline Labor productivity & 481 & 407 & 438 & 525 & 584 & 596 & 622 & 640 & 660 & 735 & 832 & 900 \\
\hline \multicolumn{13}{|l|}{ Labor Market: } \\
\hline Unemployment rate in percent & 1.2 & 6.5 & 4.8 & 7.1 & 6.5 & 5.6 & 1.7 & 8.7 & 14.5 & 18.3 & 19.8 & 20.2 \\
\hline Average gross annual wage in crowns & 43,284 & 50,916 & 62,640 & 78,432 & 92,076 & 109,296 & 128,076 & 139,356 & 151,608 & 159,612 & 161,436 & 166,524 \\
\hline Average gross annual wage in USD & 2,096 & 2,331 & 2,993 & 3,632 & 4,319 & 5,558 & 6,371 & 5,933 & 6,342 & 6,228 & 5,648 & 5,910 \\
\hline
\end{tabular}

Table 2: Jiu Valley Region

\begin{tabular}{|c|c|c|c|c|c|c|c|c|c|c|c|c|}
\hline Year & 1990 & 1991 & 1992 & 1993 & 1994 & 1995 & 1996 & 1997 & 1998 & 1999 & 2000 & 2001 \\
\hline \multicolumn{13}{|l|}{ Mines: } \\
\hline Production in thousand tons & 4,998 & 4,527 & 4,921 & 5,040 & 5,450 & 5,368 & 5,972 & 4,927 & 3,962 & 3,502 & 3,701 & 4,033 \\
\hline Employment in mines & 33,562 & 34,433 & 34,648 & 35,275 & 36,307 & 35,247 & 35,061 & 18,578 & 16,109 & 15,601 & 15,591 & 15,029 \\
\hline Labor productivity & 149 & 131 & 142 & 143 & 150 & 152 & 170 & 265 & 246 & 224 & 237 & 268 \\
\hline \multicolumn{13}{|l|}{ Labor Market: } \\
\hline Unemployment rate in percent & & & & 8.7 & 9.1 & 9.5 & 11.9 & 18.8 & 33.2 & 44.9 & 43.4 & \\
\hline Average gross annual wage in thousand lei & & & & 1,191 & 2,998 & 4,619 & 6,691 & 12,081 & 17,948 & 25,449 & 37,243 & \\
\hline Average gross annual wage in USD & & & & 2,163 & 2,500 & 3,135 & 2,994 & 2,326 & 2,791 & 2,290 & 2,367 & \\
\hline
\end{tabular}




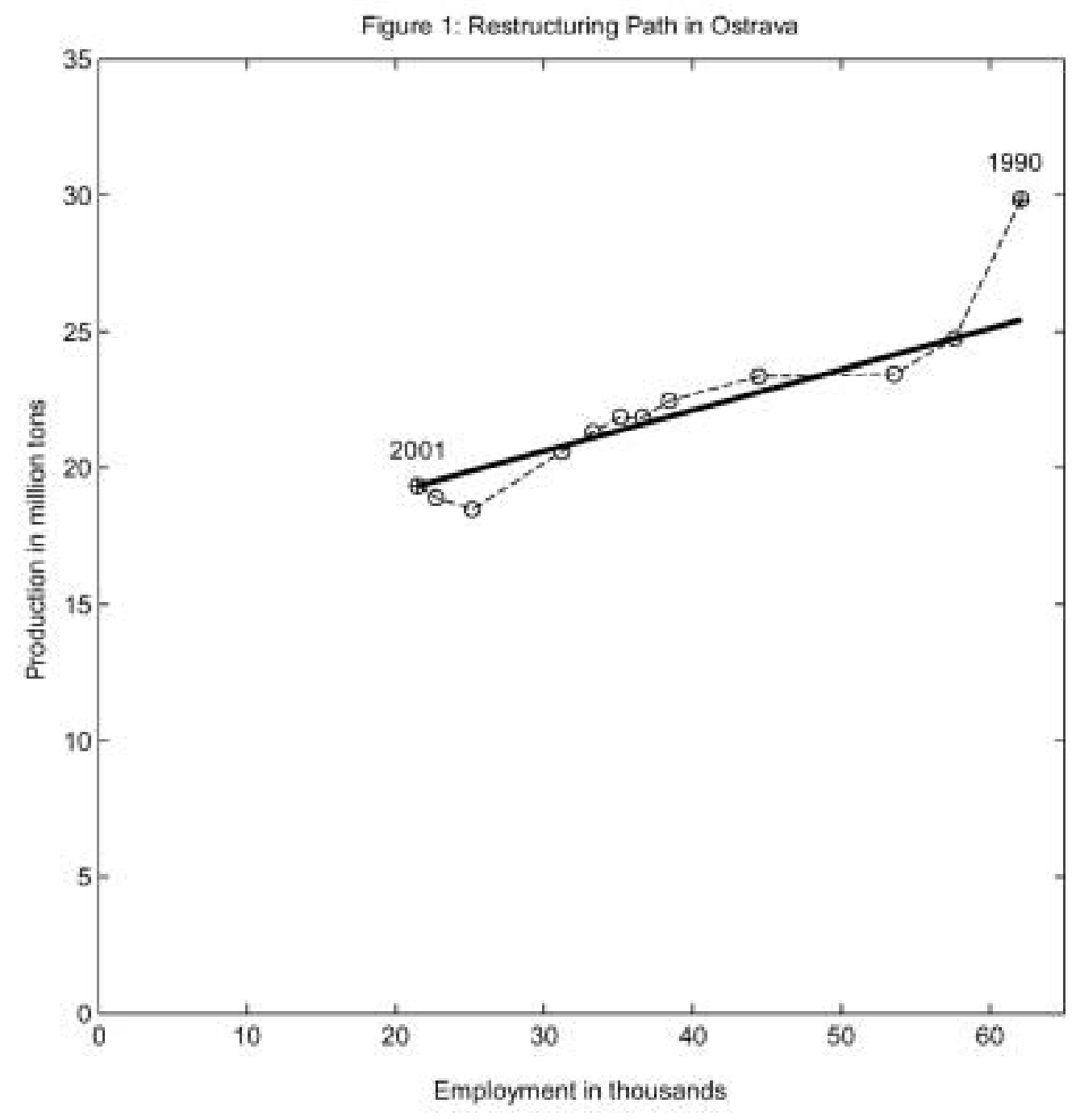


Figure 2: Restructuring Path in Ju Valley

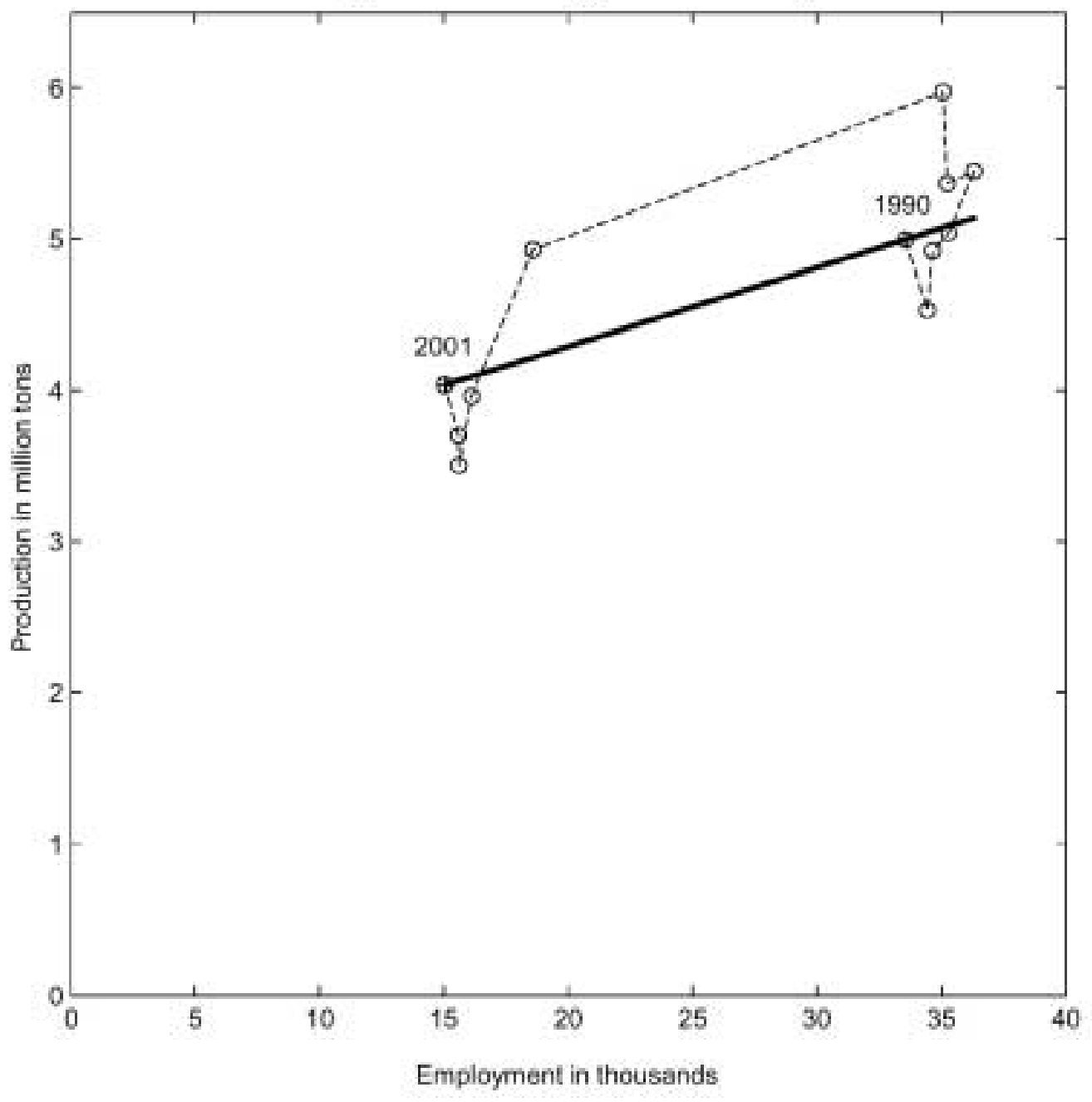


Figure 3: Welfare Path in Ostrava

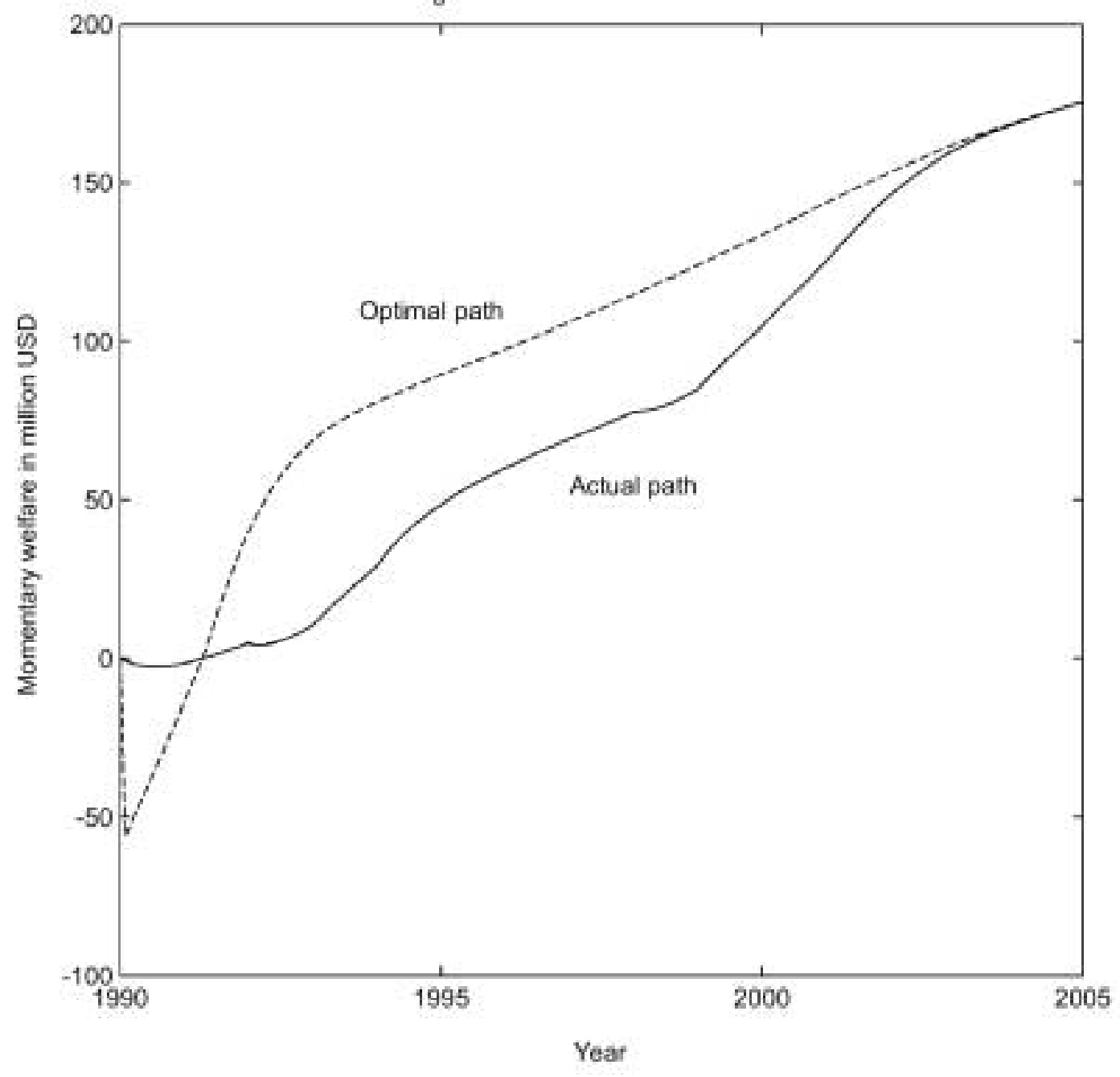




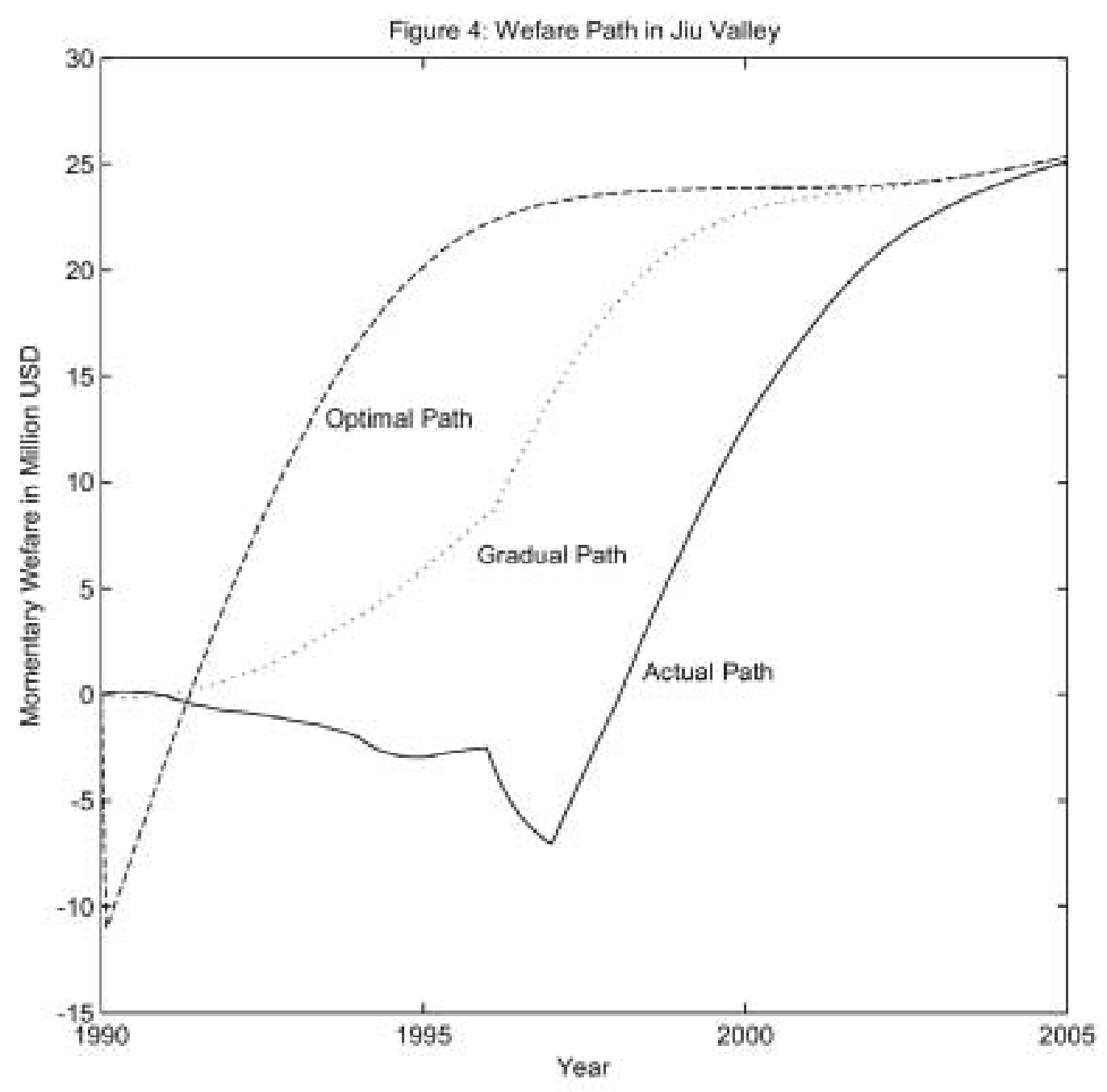




\section{DAVIDSON INSTITUTE WORKING PAPER SERIES - Most Recent Papers}

The entire Working Paper Series may be downloaded free of charge at: www.wdi.bus.umich.edu

CURRENT AS OF 5/10/05

\begin{tabular}{|c|c|c|}
\hline Publication & Authors & Date \\
\hline $\begin{array}{l}\text { No. 773: Organized Labor and Restructuring: Coal Mines in the Czech } \\
\text { Republic and Romania }\end{array}$ & $\begin{array}{l}\text { Jan Bruha, Delia Ionascu, and } \\
\text { Byeongju Jeong }\end{array}$ & May 2005 \\
\hline $\begin{array}{l}\text { No. 772: Is Political Risk Company-Specific? The Market Side of the } \\
\text { Yukos Affair }\end{array}$ & $\begin{array}{l}\text { Alexei Goriaev and Konstantin } \\
\text { Sonin }\end{array}$ & May 2005 \\
\hline $\begin{array}{l}\text { No. 771: Non-Linear Exchange Rate Dynamics in Target Zones: A } \\
\text { Bumpy Road Towards A Honeymoon }\end{array}$ & $\begin{array}{l}\text { Jesús Crespo-Cuaresma, Balázs } \\
\text { Égert, and Ronald MacDonald }\end{array}$ & May 2005 \\
\hline $\begin{array}{l}\text { No. 770: Equilibrium Exchange Rates in Southeastern Europe, Russia, } \\
\text { Ukraine and Turkey: Healthy or (Dutch) Diseased? }\end{array}$ & Balázs Égert & May 2005 \\
\hline $\begin{array}{l}\text { No. 769: Equilibrium Exchange Rates in Central and Eastern Europe: A } \\
\text { Meta-Regression Analysis }\end{array}$ & Balázs Égert and László Halpern & May 2005 \\
\hline $\begin{array}{l}\text { No. 768: Testing for inflation convergence between the Euro Zone } \\
\text { and its CEE partners }\end{array}$ & Imed Drine and Christophe Rault & Apr. 2005 \\
\hline $\begin{array}{l}\text { No. 767: Labor Mobility during Transition: Evidence from the Czech } \\
\text { Republic }\end{array}$ & Jan Fidrmuc & Apr. 2005 \\
\hline $\begin{array}{l}\text { No. 766: Formation of social capital in Central and Eastern Europe: } \\
\text { Understanding the gap vis-à-vis developed countries }\end{array}$ & Jan Fidrmuc and Klarita Gërxhani & Apr. 2005 \\
\hline $\begin{array}{l}\text { No. 765: Do Regional Integration Agreements Increase Business-Cycle } \\
\text { Convergence? Evidence From APEC and NAFTA }\end{array}$ & $\begin{array}{l}\text { Viviana Fernandez and Ali M. } \\
\text { Kutan }\end{array}$ & Apr. 2005 \\
\hline $\begin{array}{l}\text { No. 764: State Regulations, Job Search and Wage Bargaining: A Study } \\
\text { in the Economics of the Informal Sector }\end{array}$ & Maxim Bouev & Apr. 2005 \\
\hline $\begin{array}{l}\text { No. 763: The Feldstein-Horioka Puzzle Revisited: An “European- } \\
\text { Regional” Perspective }\end{array}$ & $\begin{array}{l}\text { Jérôme Hericourt and Mathilde } \\
\text { Maurel }\end{array}$ & Apr. 2005 \\
\hline $\begin{array}{l}\text { No. 762: Transatlantic Differences in Labour Markets Changes in Wage } \\
\text { and Non-Employment Structures in the 1980s and the 1990s }\end{array}$ & Patrick A. Puhani & Mar. 2005 \\
\hline $\begin{array}{l}\text { No. 761: Resolution, Recovery and Survival: The Evolution of Payment } \\
\text { Disputes in Post-Socialist Europe }\end{array}$ & William Pyle & Mar. 2005 \\
\hline $\begin{array}{l}\text { No. 760: Official Foreign Exchange Interventions in the Czech } \\
\text { Republic: Did They Matter? }\end{array}$ & Balázs Égert and Luboš Komárek & Mar. 2005 \\
\hline $\begin{array}{l}\text { No. 759: Assessing Market Expectations on Exchange Rates and } \\
\text { Inflation: A Pilot Forecasting System for Bulgaria }\end{array}$ & $\begin{array}{l}\text { Michael Berlemann, Kalina } \\
\text { Dimitrova, \& Nikolay Nenovsky }\end{array}$ & Mar. 2005 \\
\hline No. 758: Attitudes and Performance: An Analysis of Russian Workers & \begin{tabular}{|l|} 
Susan J. Linz and Anastasia \\
Semykina \\
\end{tabular} & Mar. 2005 \\
\hline $\begin{array}{l}\text { No. 757: Barter, Credit, and Welfare: A theoretical inquiry into the } \\
\text { barter phenomenon in Russia }\end{array}$ & José Noguera and Susan J. Linz & Mar. 2005 \\
\hline $\begin{array}{l}\text { No. 756: Sorting, Selection, and Transformation of the Return to } \\
\text { College Education In China }\end{array}$ & $\begin{array}{l}\text { Belton M. Fleisher, Haizheng Li, } \\
\text { Shi Li, and Xiaojun Wang }\end{array}$ & Mar. 2005 \\
\hline $\begin{array}{l}\text { No. 755: Foreign Exchange Interventions in Emerging Europe: } \\
\text { Should We Give a Damn? The Case of Croatia and Turkey }\end{array}$ & Balázs Égert and Maroje Lang & Mar. 2005 \\
\hline $\begin{array}{l}\text { No. 754: Targeting Relative Inflation Forecast as Monetary Policy } \\
\text { Framework for Adopting Euro }\end{array}$ & Lucjan T. Orlowski & Feb. 2005 \\
\hline $\begin{array}{l}\text { No. 753: Internet Entrepreneurship: Networks and Performance of } \\
\text { Internet Ventures In China }\end{array}$ & Bat Batjargal & Feb. 2005 \\
\hline $\begin{array}{l}\text { No. 752: Network Triads: Transitivity, Referral and Venture Capital } \\
\text { Decisions in China and Russia }\end{array}$ & Bat Batjargal & Feb. 2005 \\
\hline $\begin{array}{l}\text { No. 751: Software Entrepreneurship: Knowledge Networks and } \\
\text { Performance Of Software Ventures In China and Russia }\end{array}$ & Bat Batjargal & Feb. 2005 \\
\hline $\begin{array}{l}\text { No. 750: Retained State Shareholding in Chinese PLCs: Does } \\
\text { Government Ownership Reduce Corporate Value? }\end{array}$ & Lihui Tian and Saul Estrin & Feb. 2005 \\
\hline No. 749: Financial Development and Technology & Solomon Tadesse & Feb. 2005 \\
\hline No. 748: Banking Fragility and Disclosure: International Evidence & Solomon Tadesse & Feb. 2005 \\
\hline $\begin{array}{l}\text { No. 747: Consolidation, Scale Economies and Technological Change in } \\
\text { Japanese Banking }\end{array}$ & Solomon Tadesse & Feb. 2005 \\
\hline
\end{tabular}

